\title{
IMPACT OF WORK CULTURE ON MOTIVATION AND PERFORMANCE LEVEL OF EMPLOYEES IN PRIVATE SECTOR COMPANIES
}

Smrita Sinha, Ajay Kr. Singh, Nisha Gupta, Rajul Dutt

\section{Introduction}

The environment has long been recognized as a source of influence on the individual's behavior. Until recently, researchers had made few systematic attempts to explore the influences of an organization's culture on the behavior of employees. It is often suggested that culture operates as a unitary "main effect" on all people. Bodley (1994) explained the various definitions of culture, which are reflected in Table 1.

Table 1

Diverse definitions of culture

\begin{tabular}{|l|l|}
\hline Topical & $\begin{array}{l}\text { Culture consists of everything on a list of topics, or categories, such as Social } \\
\text { organization, religion, and economy. }\end{array}$ \\
\hline Historical & Culture is a social heritage, or tradition, that is passed on to future generations. \\
\hline Behavioral & Culture is shared, learned human behavior; a way of life. \\
\hline Normative & Culture is ideals, values, or rules for living. \\
\hline Mental & $\begin{array}{l}\text { Culture is a complex of ideas, or learned habits, that inhibit impulses and } \\
\text { distinguish people from animals. }\end{array}$ \\
\hline Functional & $\begin{array}{l}\text { Culture is the way humans solve problems of adapting to the environment or living } \\
\text { together. }\end{array}$ \\
\hline Structural & Culture consists of patterned and interrelated ideas, symbols, or behaviors. \\
\hline Symbolic & Culture is based on arbitrarily assigned meanings that are shared by a society. \\
\hline
\end{tabular}

Source: Bodley, 1994.

\section{Rationale for interest in organizational culture and literature review}

It is arguable that the increasing academic and practitioner interest in the topic of work culture is caused by two factors. The first is the enduring assumption that the performance of organizations is dependent on the extent to which employee values are aligned to company strategy (Blackler and Brown, 1981; Dennison, 1984; Gordon

* Smrita Sinha, Amity University, Noida; Ajay Kr. Singh, Nisha Gupta, University of Delhi; Rajul Dutt, J.P. School of Business, Meerut (drajayksingh@gmail.com). 
and DiTomasso, 1992). The second is the contentious view that work culture is subject to conscious manipulation by management, who are argued to be capable of directing culture to their desired end (Deal and Kennedy, 1982; Pascale and Athos, 1981; Peters and Waterman, 1982). In India, work culture is determined by many factors - huge differences exist between public sector and private sector companies with each having its own distinctive flavor. Most HR practitioners today face issues such as low level of motivation resulting in low morale, which bears an impact on performance. Therefore, the manufacturing sector has been considered to see the impact that work culture has on managerial motivation and performance. Work culture is essential for maximizing the value of human capital, and culture management should become a critical management competence. An important challenge for managers is to determine the most effective culture for their organization. Hence, this paper focuses on the impact that work culture has on both the role motivation and contextual performance of employees in the private manufacturing sector at the middle management level. "Contextual performance“ refers to behaviors that support the environment in which the technical core operates. Common examples of contextual performance behaviors include helping coworkers, volunteering for tasks, and defending the organization (Borman and Motowidlo, 1993).

Pattanayak (1998) has developed the notion of work culture as the human environment within which an organization's employees perform their jobs. A positive culture would improve the performance of an organization in different ways such as placing constraints on the individual's freedom of choice and providing a source of reward and punishment.

Ashkanasy et al., (2000) emphasized in their study that managers speak of developing the "right kind of culture," a "culture of quality" or a "culture of customer service," suggesting that culture has to do with certain values that managers are trying to inculcate in their organizations. Also implied in this usage is the assumption that there are better or worse cultures and stronger or weaker cultures, and that the "right" kind of culture will influence how effective the organization is. More specifically, other authors have found that the concept of culture is the key to improving organizational effectiveness (for example, Deal and Kennedy, 1982; Pascale and Athos, 1981; Peters and Waterman, 1982).

Egan et al. (2004) found that learning organizational culture is associated with IT employee job satisfaction and motivation to transfer learning.

Sledge et al. (2008) used Herzberg's two-factor theory of motivation to assess job satisfaction in the Brazilian hotel industry. The results partially support the theory and suggest that culture influences the degree of job satisfaction.

Takada and Westbrook (2009) found that culture plays a significant role in employee retention. Once data was analyzed and the hypothesis proven, this could lead companies to move toward an organic culture with an emphasis on motivators in an effort to make their organizational culture more conducive to higher employee retention.

The review of all these studies prompted us to frame the following objectives and hypotheses. 


\section{Objectives of the study}

In an effort to understand corporate culture, it must be assessed. Thus, the objective of the present study is to examine the dominant work culture prevalent in the two organizations $\mathrm{X}$ and $\mathrm{Y}$ and to study its impact on the motivational and performance level of the employees at the middle management level. The study has been conducted to:

1. Study the dominant work culture prevalent in the two private sector organizations, $\mathrm{X}$ and $\mathrm{Y}$, in the manufacturing sector.

2. Assess the correlation between the type of work culture and motivational level of employees of organizations $\mathrm{X}$ and $\mathrm{Y}$.

3. Determine the gap between desired and perceived role motivation level of employees of organizations $\mathrm{X}$ and $\mathrm{Y}$ in the private sector.

4. Assess the correlation between the type of work culture and motives of the employees of organizations $\mathrm{X}$ and $\mathrm{Y}$.

5. Study the impact of type of culture as an independent variable or predictor in explaining the variation in role motivation.

6. Study the impact of the type of work culture on the performance level between the two selected private sector organizations (X and $\mathrm{Y}$ ).

7. Assess the correlation between the type of work culture and various variables of impact of culture on performance.

\section{Research hypotheses}

Null Hypothesis "H01" - There is no dominant work culture prevalent in the selected companies in the manufacturing sector.

Alternative Hypothesis "HA1" - There is a dominant work culture prevalent in the selected companies of the manufacturing sector.

Null Hypothesis"H02" - There is no correlation between the type of organizational culture and motivation level of the employees working in the manufacturing sector.

Alternative Hypothesis "HA2" - There is a positive and significant correlation between the type of organizational culture and motivation level of the employees working in the manufacturing sector.

Null Hypothesis "H03" - No gap exists between desired and perceived role motivation in private sector organizations $\mathrm{X}$ and $\mathrm{Y}$.

Alternative Hypothesis "HA3" - A significant gap exists between desired and perceived motivation in private sector organizations $\mathrm{X}$ and $\mathrm{Y}$.

Null Hypothesis"H04" - There is no correlation between the type of work culture and motivation level of the employees working in the private manufacturing sector. 
Alternative Hypothesis "HA4" - There is a positive and significant correlation between the type of work culture and motivation level of the employees working in the private manufacturing sector.

Null hypothesis "H05" - There is no impact of the type of culture as an independent variable or predictor in explaining the variation in role motivation.

Alternative Hypothesis "HA5" - There is an impact of the type of culture as an independent variable or predictor in explaining the variation in role motivation.

Null Hypothesis"H06" - There is no impact of any type of work culture on the performance level of the employees working in the private manufacturing sector ( $\mathrm{X}$ and $\mathrm{Y}$ ).

Alternative Hypothesis "HA6" - There is a significant impact of the type of work culture on the performance level of the employees working in the private manufacturing sector ( $\mathrm{X}$ and $\mathrm{Y})$.

Null Hypothesis "H07" - There is no correlation between the type of work culture and variables of impact of work culture on performance.

Alternative Hypothesis "HA7" - There is a positive and significant correlation between the type of work culture and variables of impact of work culture on performance.

\section{Research methodology}

To measure the impact of work culture on the employees' motivation at the managerial level, a comparative study was done between two private sector companies in the manufacturing sector in India with a sample size of 250 employees at the middle management level. Descriptive and inferential statistics such as mean, standard deviation, t-values, and F-values were used to test the hypotheses. In order to study the relationship between the various independent, dependent, and background variables, Pearson product-moment correlations were computed for the total sample. One-way ANOVA was undertaken to assess the significant impact of culture as a whole on the five motives of motivation. Stepwise multiple regression analysis was undertaken to assess the significant predictors of work culture for the total sample of employees at the managerial level.

The data was analyzed by using Microsoft Excel and the Statistical Package for Social Sciences (SPSS). In order to conduct the study, a structured questionnaire was used. It was divided into three parts as described below.

The first part of the questionnaire, developed by Pareek (1997), deals with measuring organizational culture profile in terms of autocratic, bureaucratic, technocratic and entrepreneurial.

Reliability: Guttman split-half equal length and unequal length reliability for a group of 20 people was found to be 0.86 (Pareek, 1997). The researcher, in order to obtain a good estimate of the reliability of the questionnaire, computed Cronbach's alpha for a group of 20 people. The various coefficients of Cronbach's alpha revealed high reliability coefficients as shown in Table 2. 
Table 2

Cronbach's alpha for measuring the reliability of the instrument

\begin{tabular}{|c|c|c|}
\hline Cronbach's alpha & $\begin{array}{c}\text { Cronbach's alpha based on } \\
\text { standardized items }\end{array}$ & No. of items \\
\hline 0.960 & 0.994 & 32 \\
\hline
\end{tabular}

Validity: Factor analysis was applied to test the construct validity. The factors explained $69 \%$ of the variance in the organizational culture (Pareek, 1997).

The second part of the questionnaire (MAO-R), developed by Pareek (1997), assesses the role motivation level of the employees comprising twenty-five statements.

Reliability: Test-retest reliability was found by re-administering the instrument to a group of 50 persons after an interval of six weeks. The coefficient of correlation ranged between 0.40 and 0.70 , significant at the 0.001 level. This shows high stability of the instrument. Guttman sp or MAO-R Desired. The researcher, in order to obtain a good estimate of the reliability of the questionnaire, computed Cronbach's alpha.

\section{Table 3}

Cronbach's alpha for measuring the reliability of the instrument

\begin{tabular}{|c|c|}
\hline Cronbach's alpha & No. of items \\
\hline 0.907 & 25 \\
\hline
\end{tabular}

The various coefficients of Cronbach's alpha revealed high reliability coefficients as shown in table 3.

Validity: For a better insight into MAO-R, all the 25 items were factor analyzed from the response of about 500 managers. The five factors that emerged (principal component method with varimax rotation) were: achievement, influence, control, affiliation, and extension. These factors explain $100 \%$ of the variance.

The third part of the questionnaire, 'Impact of Work Culture on Performance' (IWCP), developed by the researcher, assesses the impact of culture on performance of the employees of the private sector. For each item, a statement is presented and subjects respond using a four-point scale, ranging from "strongly agree" (4) to "strongly disagree" (1). In order to obtain a good estimate of the reliability of the questionnaire, Cronbach's alpha and the split-half technique, i.e., to split the items into two groups and then compare these groups as if they were two separate administrations of the same survey, were computed. 


\section{Table 4}

Cronbach's alpha, Spearman-Brown's and Guttman's splithalf coefficients for measuring reliability of the instrument

\begin{tabular}{|c|c|c|}
\hline Cronbach's alpha coefficients & \multicolumn{2}{|c|}{ Spearman-Brown coefficients } \\
\cline { 2 - 3 } & Equal length split-half & Guttman's split-half \\
\hline 0.921 & 0.959 & 0.903 \\
\hline
\end{tabular}

The various coefficients of Cronbach's alpha, Spearman-Brown's equal length split-half and Guttman's split-half techniques all revealed high reliability coefficients as shown in Table 4.

Validity: Validity was established during the preparation of the scales. Some experts were used as judges for rating the statements for their relevance to various value dimensions. The criterion for the selection of the statements was the unanimity of the judges (at least 80 percent). This ensured the validity of the item in indicating the status of an individual on the value dimensions concerned. Since the scoring system was a priori determined $(4,3,2,1)$, the scales may be called absolute scales, in the sense that they are not affected by the distribution pattern of the scores in the group under study.

\section{Analysis and results}

In this study, the results were obtained as a consequence of statistical analysis of the data, which have been interpreted in the light of proposed objectives and hypotheses as depicted in various tables. Table 5 shows the dominant work culture prevalent in the two selected organizations.

\section{Table 5}

Combined mean scores of employees at the managerial level in both companies $X$ and $Y$ (private sector)

\begin{tabular}{|l|c|c|}
\hline Type of culture & Mean & Std. deviation \\
\hline Autocratic & 2.9605 & 0.68968 \\
Bureaucratic & 2.3950 & 0.14206 \\
Technocratic & 2.2135 & 0.58177 \\
Entrepreneurial & 2.5410 & 0.55310 \\
\hline
\end{tabular}

By comparing the mean scores of different cultural profiles that existed in the two selected companies $\mathrm{X}$ and $\mathrm{Y}$, which are in the private sector, the findings reflected that all the four cultures (autocratic, bureaucratic, technocratic, and entrepreneurial) existed but in varying degrees, which is reflected in their mean values.

By comparing the values of different cultural profiles that existed in the two private sector companies $\mathrm{X}$ and $\mathrm{Y}$ as shown in Table 5, the findings reflected that all the four cultures existed but the most dominant among them was the autocratic culture 
$(M=2.9605)$, followed by the entrepreneurial culture $(M=2.5410)$, bureaucratic culture $(\mathrm{M}=2.3950)$, and the least dominant technocratic culture $(\mathrm{M}=2.2135)$.

\section{Table 6}

Comparison of the organizations with respect to type of work culture prevalent in the selected organizations $X$ and $Y$ (private sector)

\begin{tabular}{|l|c|c|c|c|}
\hline \multirow{2}{*}{ Type of culture } & Company & Mean & Std. deviation & \multirow{2}{*}{ T-value } \\
\hline \multirow{2}{*}{ Autocratic } & $\mathrm{X}$ & $\mathbf{3 . 5 3}$ & 0.083 & \multirow{2}{*}{$68.066^{*}$} \\
\cline { 2 - 4 } & $\mathrm{Y}$ & 2.48 & 0.100 & \\
\hline \multirow{2}{*}{ Bureaucratic } & $\mathrm{X}$ & 1.74 & 0.299 & \multirow{2}{*}{$265.507^{\star}$} \\
\cline { 2 - 4 } & $\mathrm{Y}$ & 2.20 & 0.362 & \\
\hline \multirow{2}{*}{ Technocratic } & $\mathrm{X}$ & 2.39 & 0.542 & \multirow{2}{*}{$60.190^{\star}$} \\
\cline { 2 - 4 } & $\mathrm{Y}$ & 2.31 & 0.123 & \\
\hline \multirow{2}{*}{ Entrepreneurial } & $\mathrm{X}$ & 2.68 & 0.371 & \multirow{2}{*}{$72.658^{\star}$} \\
\cline { 2 - 4 } & $\mathrm{Y}$ & $\mathbf{2 . 8 8}$ & 0.498 & \\
\hline
\end{tabular}

* Significant at the 0.05 level (2-tailed).

Mean scores as listed in Table 6 show that the organization $\mathrm{X}$ is dominated by an autocratic culture $(\mathrm{M}=3.53)$ and the organization $\mathrm{Y}$ is dominated by an entrepreneurial culture $(\mathrm{M}=2.88)$. T-values as shown in Table 6 show that there is a significant difference with respect to the type of culture prevalent in the organizations in the private sector. Thus, the null hypothesis "H01" is rejected and the alternative hypothesis "HA1" is accepted: there is a dominant culture prevalent in the private sector organizations.

Table 7

Relationship (correlation coefficient) between type of culture and role motivation

\begin{tabular}{|l|c|}
\hline Type of culture & Correlation \\
\hline Autocratic & $-0.427^{\star}$ \\
\hline Bureaucratic & $-0.397^{\star}$ \\
\hline Technocratic & $\mathbf{0 . 5 6 0 ^ { \star }}$ \\
\hline Entrepreneurial & $0.274^{\star}$ \\
\hline
\end{tabular}

* Correlation is significant at the 0.01 level (2-tailed).

Table 7 shows that there exists a negative and significant correlation between the autocratic culture and role motivation $(\mathrm{r}=-0.427)$. If the autocratic culture is increasing, then the level of satisfaction is decreasing, i.e., the level of employees' dissatisfaction with their roles is increasing and the level of motivation is being lowered. Similarly, there is a negative correlation between the bureaucratic culture and motivation $(r=-0.397)$. On the other hand, the technocratic culture has a positive correlation 
with motivation $(r=0.560)$, which implies that if the technocratic culture increases, then the employees feel strongly motivated and experience a high level of satisfaction with their roles. Similar results can be seen for the entrepreneurial culture $(\mathrm{r}=0.274)$, which also has a positive correlation with motivation. Hence, the null hypothesis "H02" stands rejected and the alternative hypothesis "HA2" is accepted: there is a correlation between the type of organizational culture and motivation level of employees of an organization in the private sector.

Table 8 shows the combined mean scores for a gap between the desired and perceived motivation level of the employees in private sector organizations $\mathrm{X}$ and $\mathrm{Y}$ to test the hypothesis $\mathrm{H03}$ that no gap exists between desired and perceived role motivation in the private sector organizations $X$ and $Y$.

\section{Table 8}

Combined mean scores of the gap between desired and perceived role motivation levels of employees at the managerial level in both the companies $X$ and $Y$

\begin{tabular}{|l|c|c|c|}
\hline Needs & $\mathbf{N}$ & Mean & Std. deviation \\
\hline Achievement & 250 & $\mathbf{1 . 7 4 4 8}$ & 1.19423 \\
\hline Influence & 250 & 1.3944 & 0.86082 \\
\hline Control & 250 & 1.5888 & 1.61435 \\
\hline Affiliation & 250 & 0.8024 & 0.71798 \\
\hline Extension & 250 & $\mathbf{1 . 7 2 4 0}$ & 1.08357 \\
\hline
\end{tabular}

Role motivation can be defined as the gap between perceived and desired satisfaction of the main psychological needs in one's organizational role. The higher the score, the higher the level of dissatisfaction with the role that the employee has, i.e., (s)he is not getting sufficient opportunities in her/his role to pursue matters of achievement and extension as reflected in Table 8. The combined mean scores show that the mean scores of achievement $(M=1.7448)$ and extension $(M=1.7240)$ are more than those of the other needs, which explains that employees in private sector organizations do not have sufficient opportunities to pursue matters of excellence, competition in terms of standards being set by others or by oneself, the setting of challenging goals for oneself, awareness of the obstacles that might be encountered in attempting to achieve these goals, and persistence in trying alternative paths to one's goals. Extension is characterized by a concern for others, interest in superordinate goals, and an urge to be relevant and useful to large groups, including society, which is not fulfilled in the private sector as shown in Table 8 . 
Table 9

Comparison of the organizations with respect to role motivation levels of employees in the selected organizations $X$ and $Y$

\begin{tabular}{|c|c|c|c|c|}
\hline Needs & Company & Mean & Std. deviation & T-test \\
\hline \multirow{2}{*}{ Achievement } & $x$ & 0.8192 & 0.21011 & \multirow[t]{2}{*}{$23.101^{*}$} \\
\hline & $Y$ & 2.6704 & 1.04519 & \\
\hline \multirow{2}{*}{ Influence } & $x$ & 0.7968 & 0.38770 & \multirow[t]{2}{*}{$25.612^{*}$} \\
\hline & $\mathrm{Y}$ & 1.9920 & 0.78592 & \\
\hline \multirow{2}{*}{ Control } & $x$ & 2.7024 & 0.61046 & \multirow[t]{2}{*}{$15.561^{*}$} \\
\hline & $\mathrm{Y}$ & 0.4752 & 1.53637 & \\
\hline \multirow{2}{*}{ Affiliation } & $X$ & 1.0144 & 0.44950 & \multirow[t]{2}{*}{$17.670 *$} \\
\hline & $Y$ & 0.5904 & 0.86168 & \\
\hline \multirow{2}{*}{ Extension } & $X$ & 0.8992 & 0.28241 & \multirow[t]{2}{*}{$25.157^{*}$} \\
\hline & $\mathrm{Y}$ & 2.5488 & 0.95204 & \\
\hline
\end{tabular}

* Significant at the 0.05 level (2-tailed).

Mean scores as shown in Table 9 reveal that the employees of company $\mathrm{X}$ would like to have more control over the resources, concern for orderliness, a desire to be informed about everything, an urge to monitor events and to take corrective action when needed, and a need to display personal power. Table 9 exhibits their level of dissatisfaction with the need to control $(\mathrm{M}=2.7024)$. However, their other needs are comparatively lower, which shows that in comparison to the need to control, their other needs are being taken care of. Similarly, mean scores of company Y show that employees would like to be given more opportunities to exhibit excellence, competition in terms of standards, and setting up of challenging goals in order to achieve higher objectives (achievement motive $\mathrm{M}=2.6704$ ). T-values show that there is a significant difference with respect to the significant gap that exists between desired and perceived role motivation in the private sector organizations. Hence, the Null Hypothesis "H03" stands rejected and the Alternative Hypothesis "HA3" is accepted: a significant gap exists between desired and perceived motivation in private sector organizations $\mathrm{X}$ and $\mathrm{Y}$.

Table 10

Combined correlation between the type of work culture and needs of the employees of organizations $X$ and $Y$

\begin{tabular}{|c|c|c|c|c|c|}
\hline Culture $\backslash$ Need & Achievement & Influence & Control & Affiliation & Extension \\
\hline Autocratic & $-0.935^{\star \star}$ & $-0.834^{\star \star}$ & $0.905^{\star \star}$ & $0.410 * \star$ & $-0.902^{\star \star}$ \\
\hline Bureaucratic & $-0.755^{\star \star}$ & $-0.580 * *$ & $0.869^{\star \star}$ & $0.522^{\star *}$ & $-0.691 * *$ \\
\hline Technocratic & $0.885^{\star *}$ & 0.850 ** & $-0.767^{\star \star *}$ & $-0.273^{\star \star}$ & $0.876^{\star \star}$ \\
\hline Entrepreneurial & $0.788^{\star *}$ & $0.597^{* *}$ & $-0.919 * *$ & $-0.555^{\star \star}$ & $0.718^{* *}$ \\
\hline
\end{tabular}

** Correlation is significant at the 0.01 level (2-tailed). 
As can be seen from Table 10, the autocratic culture is positively correlated with the need for control $(r=0.905)$ and the need for affiliation $(r=0.410)$. This shows that in the autocratic culture, the need for power is dominant but, along with it, the concern for others is also high. Similarly, in the bureaucratic culture, the degree of control $(\mathrm{r}=0.869)$ and affiliation $(\mathrm{r}=0.522)$ are positive and high in comparison to other needs, but marginally less than in the autocratic culture. Contrary to the above mentioned results, in the technocratic culture, the need of employees to achieve more is higher along with the need for making an impact on others keeping in mind the others' interests and goals. As seen from the table, the technocratic culture is positively correlated with achievement $(\mathrm{r}=0.885)$, extension $(\mathrm{r}=0.876)$, and influence $(\mathrm{r}=0.850)$. Similarly, in the entrepreneurialculture, the achievement $(\mathrm{r}=0.788)$, influence $(\mathrm{r}=0.597)$, and extension $(\mathrm{r}=0.718)$ needs are more prevalent in comparison to the other two motives. Hence, the Null Hypothesis "H04" stands rejected and the Alternative Hypothesis "HA4" is accepted: there is a positive and significant correlation between the type of work culture and motivation level of the employees working in the private manufacturing sector.

Table 11

Model summary: Stepwise selection of variables in the regression model

\begin{tabular}{|c|c|c|c|c|c|c|c|c|}
\hline & $\mathbf{R}$ & $\begin{array}{c}\mathbf{R} \\
\text { square }\end{array}$ & $\begin{array}{c}\text { Adjusted } \\
\mathbf{R} \text { square }\end{array}$ & $\begin{array}{c}\text { Std. } \\
\text { error } \\
\text { of the } \\
\text { estimate }\end{array}$ & $\begin{array}{c}\mathbf{R} \\
\text { square } \\
\text { change }\end{array}$ & $\begin{array}{c}\mathbf{F} \\
\text { Change }\end{array}$ & $\begin{array}{c}\text { Sig. F } \\
\text { change }\end{array}$ & Variable in \\
\hline 1 & $0.560(\mathrm{a})$ & 0.313 & 0.311 & 0.40911 & 0.313 & 111.872 & 0.000 & $\begin{array}{c}\text { Technocratic } \\
\text { culture }\end{array}$ \\
\hline 2 & $0.592(\mathrm{~b})$ & 0.350 & 0.345 & 0.39875 & 0.037 & 13.896 & 0.000 & $\begin{array}{c}\text { Bureaucratic } \\
\text { culture }\end{array}$ \\
\hline
\end{tabular}

Dependent variable: motivation.

An application of stepwise regression analysis for the independent and dependent variables produced two (2) variables as the best predictors of the role motivation in the two selected companies $\mathrm{X}$ and $\mathrm{Y}$. The combination includes the technocratic and bureaucratic cultures. R2 explains that approximately $35.0 \%$ of the variation in the role motivation is caused by the 2 variables selected in the regression model. When adjusted for the number of variables, it (adjusted R2) shows that it accounts for 34.5\% of the variation in the role motivation. The significance of the $\mathrm{F}$-value $(\mathrm{P}<0.01)$ shows that the high $\mathrm{R} 2$ is not simply an aberration due to sampling error. Thus, the R2 value gives an indication about the importance of the technocratic and bureaucratic cultures in explaining a significant amount of variation in the role motivation. 
Table 12

Associated statistics for the determinants of motivation in companies $X$ and $Y$

\begin{tabular}{|l|c|c|c|c|c|c|c|c|}
\hline \multirow{2}{*}{ Variables } & $\begin{array}{c}\text { Non-standardized } \\
\text { coefficients }\end{array}$ & $\begin{array}{c}\text { Standardized } \\
\text { coefficients }\end{array}$ & \multirow{2}{*}{ t } & \multicolumn{2}{c|}{ Sig. } & \multicolumn{2}{c|}{ Correlations } \\
\cline { 2 - 9 } & B & Std. Error & & & $\begin{array}{c}\text { Zero- } \\
\text { order }\end{array}$ & Partial & Part \\
\hline (Constant) & -3.772 & 0.357 & & -10.562 & 0.000 & & & \\
\hline Technocratic culture & 0.598 & 0.070 & 0.907 & 8.519 & 0.000 & 0.560 & 0.479 & 0.440 \\
\hline Bureaucratic culture & 0.242 & 0.065 & 0.397 & 3.728 & 0.000 & -0.397 & 0.232 & 0.192 \\
\hline
\end{tabular}

As shown in Table 12, the technocratic culture emerges as the variable with the largest 'pure' $(\mathrm{B}(\mathrm{s})=0.907)$ impact on motivation. The t-values and the significance of the $t$ in the tables specify the significance of the individual beta coefficients. As reflected, betas for all the variables are statistically significant at the $99 \%$ level of confidence. The technocratic culture has the strongest partial correlation or the purest relationship with the role motivation $(47.9 \%)$. It is the best predictor of the role motivation, followed by the bureaucratic culture (23.2\%). The standardized betas do not tell how much each variable contributes to explaining the variability in the dependent variable. Therefore, some scholars are of the view that squared part correlations should be used for this purpose (Tabachnick and Fidell, 1983; Bordens and Abbott, 1996). Hence, the technocratic culture explains $19.36 \%$ of the variation and the bureaucratic culture explains $3.68 \%$ of the variation in the motivation level of employees. This rejects the null hypothesis "H05" and the alternative hypothesis "HA5"is accepted: there is an impact of the type of culture as an independent variable or predictor in explaining the variation in the role motivation and, hence, culture contributes significantly to the motivation level of employees working in the two selected organizations.

Table 13 shows the impact that culture as a whole has on the five needs (achievement, influence, control, affiliation, and extension) of the role motivation in the selected private sector companies. 
Table 13

One-way ANOVA determining the impact of culture on the 5 motives of motivation

\begin{tabular}{|c|c|c|c|c|c|c|}
\hline Motives & & $\begin{array}{l}\text { Sum of } \\
\text { squares }\end{array}$ & Df & $\begin{array}{c}\text { Mean } \\
\text { square }\end{array}$ & $\mathbf{F}$ & Sig. \\
\hline Achievement & $\begin{array}{c}\text { between groups } \\
\text { within groups } \\
\text { total }\end{array}$ & $\begin{array}{r}307.225 \\
47.894 \\
355.118\end{array}$ & $\begin{array}{r}16 \\
233 \\
249\end{array}$ & $\begin{array}{r}19.202 \\
0.206\end{array}$ & 93.414 & 0.000 \\
\hline Influence & $\begin{array}{c}\text { between groups } \\
\text { within groups } \\
\text { total }\end{array}$ & $\begin{array}{r}133.051 \\
51.462 \\
184.512\end{array}$ & $\begin{array}{r}16 \\
233 \\
249\end{array}$ & $\begin{array}{l}8.316 \\
0.221\end{array}$ & 37.650 & 0.000 \\
\hline Control & $\begin{array}{c}\text { between groups } \\
\text { within groups } \\
\text { total }\end{array}$ & $\begin{array}{r}579.404 \\
69.524 \\
648.929\end{array}$ & $\begin{array}{r}16 \\
233 \\
249\end{array}$ & $\begin{array}{r}36.213 \\
0.298\end{array}$ & 121.362 & 0.000 \\
\hline Affiliation & $\begin{array}{c}\text { between groups } \\
\text { within groups } \\
\text { total }\end{array}$ & $\begin{array}{r}39.400 \\
88.959 \\
128.359\end{array}$ & $\begin{array}{r}16 \\
233 \\
249\end{array}$ & $\begin{array}{l}2.462 \\
0.382\end{array}$ & 6.450 & 0.000 \\
\hline Extension & $\begin{array}{c}\text { between groups } \\
\text { within groups } \\
\text { total }\end{array}$ & $\begin{array}{r}237.876 \\
54.480 \\
292.356\end{array}$ & $\begin{array}{r}16 \\
233 \\
249\end{array}$ & $\begin{array}{r}14.867 \\
0.234\end{array}$ & 63.585 & 0.000 \\
\hline
\end{tabular}

According to Table 13, there is a significant impact of culture as a whole on the needs of the role motivation. As exhibited in Table 13, the critical F-value in the table $(\mathrm{F}=1.68)$ is lower than the calculated value for all the five needs of the role motivation. Alternatively, the significant value comparing the culture as a whole and needs of the employees is less than the table value $(\alpha=0.05)$. Therefore, there is a significant impact of culture as a whole on the needs of the role motivation at the 0.05 level.

Table 14

Combined mean scores of the impact of dominant work culture on the performance of employees at the managerial level in both the companies $X$ and $Y$ (private sector)

\begin{tabular}{|l|c|c|c|c|}
\hline Types of culture & $\mathbf{N}$ & Mean & Std. deviation & Variance \\
\hline Autocratic & 250 & 3.2710 & 1.18927 & 1.414 \\
\hline Bureaucratic & 250 & 2.5770 & 0.96579 & 0.933 \\
\hline Technocratic & 250 & 2.4640 & 0.87457 & 0.765 \\
\hline Entrepreneur & 250 & 2.8240 & 0.94992 & 0.902 \\
\hline Valid N & 250 & & & \\
\hline
\end{tabular}


According to Table 14, the autocratic culture $(\mathrm{M}=3.2710)$ has a high degree of impact on the performance of the employees at the middle management level. This means that in the private manufacturing sector, a high level of control is exercised on all critical matters of concern which involve decision making by the significant few of the top-level management. There is a high degree of supervision at the middle management level. The entrepreneurial culture $(\mathrm{M}=2.8240)$ scores the second-highest with respect to the impact on the performance of employees. However, the technocratic culture $(\mathrm{M}=2.4640)$ has the lowest scores as compared to the other cultures, i.e., in private sector organizations, independence and innovation do not play a significant role in performance.

\section{Table 15}

Comparison of the organizations with respect to impact of work culture on performance of employees in the selected organizations $X$ and $Y$ (private sector)

\begin{tabular}{|l|c|c|c|c|}
\hline $\begin{array}{l}\text { Types of } \\
\text { culture }\end{array}$ & Company & Mean & Std. deviation & \multirow{2}{*}{ T-value } \\
\hline \multirow{2}{*}{ Autocratic } & $\mathrm{X}$ & 3.3480 & .50006 & \multirow{2}{*}{$35.008^{\star}$} \\
\cline { 2 - 4 } & $\mathrm{Y}$ & 2.6480 & .96934 & \\
\hline \multirow{2}{*}{ Bureaucratic } & $\mathrm{X}$ & 2.2640 & .73115 & \multirow{2}{*}{$33.842^{\star}$} \\
\cline { 2 - 4 } & $\mathrm{Y}$ & 1.8326 & .91841 & \\
\hline \multirow{2}{*}{ Technocratic } & $\mathrm{X}$ & 1.5440 & .46652 & \multirow{2}{*}{$32.759^{\star}$} \\
\cline { 2 - 4 } & $\mathrm{Y}$ & 2.7920 & 1.08160 & \\
\hline \multirow{2}{*}{ Entrepreneur } & $\mathrm{X}$ & 3.3069 & .44393 & \multirow{2}{*}{$33.886^{\star}$} \\
\cline { 2 - 4 } & $\mathrm{Y}$ & 3.3860 & .71103 & \\
\hline Valid N (listwise) & & & & \\
\hline
\end{tabular}

* Significant at the 0.05 level (2-tailed).

According to Table 15, it can be seen that in company X, the autocratic culture $(\mathrm{M}=3.3480)$ has a high impact on performance. This means that in company $\mathrm{X}$, decision making through hierarchies increases the performance of employees. However, in company $\mathrm{Y}$, the entrepreneurial culture $(\mathrm{M}=3.3860)$ shows a high impact wherein initiatives such as training need analysis, competency mapping, empowerment, participatory style of decision making, etc., lead to a high level of influence on the performance of the employees at the middle management level. However, company Y has the lowest degree of bureaucratic culture $(\mathrm{M}=1.8326)$. T-values as shown in Table 15 show that there are significant differences with respect to the impact of culture on the performance of employees in private manufacturing organizations $\mathrm{X}$ and $\mathrm{Y}$. 
Table 16

Model summary: Stepwise selection of variables in the regression model (private sector)

\begin{tabular}{|c|c|c|c|c|c|c|c|}
\hline R & R square & $\begin{array}{c}\text { Adjusted } \\
\text { R square }\end{array}$ & $\begin{array}{c}\text { Std. error } \\
\text { of the } \\
\text { estimate }\end{array}$ & $\begin{array}{c}\text { R square } \\
\text { change }\end{array}$ & F change & $\begin{array}{c}\text { Sig. F } \\
\text { change }\end{array}$ & Variables in \\
\hline $0.857(\mathrm{a})$ & 0.734 & 0.733 & 0.46616 & 0.734 & 683.326 & 0.000 & Technocratic culture \\
\hline $0.874(\mathrm{~b})$ & 0.764 & 0.763 & 0.43935 & 0.031 & 32.199 & 0.000 & Entrepreneurial culture \\
\hline
\end{tabular}

Dependent variable: performance in private sector organizations $\mathrm{X}$ and $\mathrm{Y}$.

An application of stepwise regression analysis for the above mentioned independent and dependent variables produced two (2) variables as the best predictors of the impact of culture on the performance in the two selected companies X and Y (Table 16). The combination of the technocratic culture and the entrepreneurial culture has a variation in the impact of culture on the performance. R2 explains that approximately $76.4 \%$ of the variation in the impact of culture on the performance is caused by the technocratic and entrepreneurial cultures selected in the regression model. When adjusted for the number of variables, it (adjusted R2) shows that it accounts for $76.3 \%$ of the variation in the impact of culture on the performance. Thus, the $\mathrm{R} 2$ value gives an indication about the importance of the technocratic and entrepreneurial cultures in explaining a significant amount of variation in the impact of culture as a whole on the performance.

Table 17

Associated statistics for the determinants of motivation in companies $X$ and $Y$

\begin{tabular}{|c|c|c|c|c|c|c|c|c|}
\hline \multirow{2}{*}{ Model } & \multicolumn{2}{|c|}{$\begin{array}{l}\text { Non-standardized } \\
\text { coefficients }\end{array}$} & \multirow[t]{2}{*}{$\begin{array}{c}\text { Standardized } \\
\text { coefficients }\end{array}$} & \multirow[t]{2}{*}{$t$} & \multirow[t]{2}{*}{ Sig. } & \multicolumn{3}{|c|}{ Correlations } \\
\hline & B & Std. Error & & & & $\begin{array}{l}\text { Zero- } \\
\text { order }\end{array}$ & Partial & Part \\
\hline (Constant) & 5.796 & 0.135 & & 42.908 & 0.000 & & & \\
\hline Technocratic & 1.108 & 0.061 & 0.716 & -18.083 & 0.000 & -0.857 & 0.755 & 0.558 \\
\hline Entrepreneurial & 0.366 & 0.064 & 0.225 & -5.674 & 0.000 & -0.673 & 0.340 & 0.175 \\
\hline
\end{tabular}

Dependent variable: performance in private sector organizations $\mathrm{X}$ and $\mathrm{Y}$.

As shown in Table 17, the technocratic culture emerges as the variable with the largest 'pure' $(\mathrm{B}(\mathrm{s})=0.716)$ impact on motivation. As reflected, betas for all the variables are statistically significant at the $99 \%$ level of confidence. The technocratic culture has the strongest partial correlation or the purest relationship with the impact of work culture on the performance (75.5\%). It is the best predictor of the impact of culture on the performance, followed by the entrepreneurial culture (34\%). Using squared part correlations, the technocratic culture explains $55.8 \%$ of the variation and the entrepreneurial culture explains $17.5 \%$ of the variation in the impact of work culture on the performance of employees. 
This rejects the null hypothesis "H06" and the alternative hypothesis "HA6" is accepted: there is a significant impact of the type of work culture on the performance level of the employees working in the private manufacturing sector ( $\mathrm{X}$ and $\mathrm{Y}$ ).

Table 18

Correlation between type of work culture and variables of impact of work culture on performance

\begin{tabular}{|c|c|c|c|c|}
\hline IWCP & Autocratic & Bureaucratic & Technocratic & \\
\hline Career planning & $-0.917^{\star \star}$ & $-0.684 * *$ & $0.917^{* *}$ & $0.677^{\star *}$ \\
\hline Training need analysis & $-0.897^{* *}$ & -0.694 ** & $0.908 * *$ & 0.674 ** \\
\hline Participative decision making & $-0.813^{\star *}$ & $-0.620 * \star$ & $0.814^{\star *}$ & $0.612^{* \star}$ \\
\hline Empowerment & $-0.904^{\star *}$ & $-0.653^{* *}$ & $0.890 * *$ & $0.647^{* *}$ \\
\hline Learning and development & $-0.846^{\star \star}$ & $-0.670 * \star$ & $0.859 * *$ & $0.667 * \star$ \\
\hline Loyalty and commitment & $-0.892^{* *}$ & $-0.681 * *$ & $0.900 * *$ & $0.668 * *$ \\
\hline Leadership & $-0.866^{* *}$ & $-0.658 * *$ & $0.872^{\star *}$ & $0.652^{* *}$ \\
\hline Competency mapping & $-0.888 * \star$ & $-0.624 * *$ & $0.872^{\star \star}$ & $0.626 * \star$ \\
\hline Turnover & $-0.875^{\star \star}$ & $-0.619 * *$ & $0.857^{* *}$ & $0.619 * *$ \\
\hline Independence & $-0.875^{\star \star}$ & $-0.619 * *$ & $0.857^{\star *}$ & $0.619 * \star$ \\
\hline Innovation & $-0.868 * \star$ & $-0.681 * *$ & $0.880 * \star$ & $0.684 * \star$ \\
\hline Merit & $-0.895^{\star *}$ & $-0.699 * *$ & $0.909 * *$ & $0.683^{* *}$ \\
\hline Grievance redressal & $-0.926^{* *}$ & $-0.667^{* *}$ & $0.918 * *$ & $0.658^{* *}$ \\
\hline Supervision & $0.866^{* *}$ & $0.680 * *$ & $-0.882^{* *}$ & $-0.644^{* *}$ \\
\hline Hierarchy & $0.703 * *$ & $0.884^{* *}$ & $-0.900 * *$ & $-0.690 * *$ \\
\hline
\end{tabular}

** Correlation is significant at the 0.01 level (2-tailed).

Table 18 shows that the autocratic culture is positively correlated with only two variables, i.e., supervision $(r=0.866)$ and hierarchy $(r=0.703)$, while it has a negative correlation with the other variables such as career planning, empowerment, leadership, etc. Similarly, the bureaucratic culture also has a significant positive correlation with supervision $(\mathrm{r}=0.680)$ and hierarchy $(\mathrm{r}=0.884)$ but the latter is comparatively higher. There is a positive and significant correlation of the technocratic culture with all the variables, with specific reference to grievance redressal $(r=0.918)$, career planning $(r=0.917)$, appraisal system based on merit $(r=0.909)$, etc., except those of supervision and hierarchy. However, the entrepreneurial culture has a positive correlation with innovation $(\mathrm{r}=0.684)$, performance appraisal based on merit $(\mathrm{r}=0.683)$, career planning $(r=0.677)$, etc., but the degree of correlation is lower than in the technocratic Culture, which is regarded as the apex culture. This shows that there is a significant correlation between the type of work culture and the variables of the 
impact of work culture on the performance. This rejects the null hypothesis "H07" and the alternative hypothesis "HA7"is accepted: there is a positive and significant correlation between the type of work culture and variables of the impact of work culture on the performance.

\section{Discussion and conclusions}

Although much research is needed, it is clear that most enduring influences are cultural. The powerful, pervasive role that work culture plays in shaping organizational life lends plausibility to speculations that cultural factors are linked with the motivation and performance (context-based) levels of the employees at the middle management level. The study suggests that if an organization's culture is to contribute to enhancing performance, it must be both "dominant" and possess distinctive "traits": particular values, beliefs, and shared behavior patterns. Some scholars have claimed that positive cultural traits boost performance in proportion to the strength of their manifestation.

The main objective of the study was to investigate the type of culture that is found dominant in the private manufacturing sector. The results show that organization $\mathrm{X}$ is dominated by an autocratic culture while organization $\mathrm{Y}$ is dominated by an entrepreneurial culture and there is a significant difference with respect to the profile of the culture type prevalent in the two organizations. Thus, it is accepted that there is a dominant culture prevalent in each of the two organizations $\mathrm{X}$ and $\mathrm{Y}$.

The other objective was to measure the impact of the work culture on the managerial motivation level. The results show that there exists a positive and significant correlation between the technocratic culture and role motivation $(r=0.560)$, followed by a negative and significant correlation between the autocratic culture and role motivation $(r=-0.427)$. This implies that the technocratic culture, if dominant, enhances the motivation level of the employees at the middle management level. At the same time, the autocratic culture, if dominant, leads to a higher level of dissatisfaction with the same. The results also show that there exists a gap between the perceived and desired levels of employees' satisfaction with their roles in the two private sector organizations. The middle management level employees of organization $\mathrm{X}$ expressed the need for having more opportunities to exercise control $(\mathrm{M}=2.7024)$. This shows that teaming and control over the work environment leads to a higher level of motivation. Middle management level employees in organization $\mathrm{Y}$ exhibited a higher level of dissatisfaction with respect to their need for achievement $(M=2.6704)$. Also, an application of stepwise regression analysis shows that different types of culture contribute significantly to the motivation level of the managerial level employees in private sector manufacturing organizations.

The organization has its own structure and goals. One's role is defined by the function one performs in response to the expectations of the significant members of the organization. Performance of employees at the middle management level depends on the dominant culture as to how much significance is attached to the roles of employees 
at the middle management level. The results highlight that the autocratic culture $(\mathrm{M}=3.2710)$ has a high degree of impact on the performance of the employees at the middle management level in the private manufacturing organizations $\mathrm{X}$ and $\mathrm{Y}$. The managers work under a high degree of supervision. After seeing a lot of companies trip up in the last global meltdown, Khanna (2010), Professor at Harvard Business School, in an extensive discussion with Business World, "Focus on Mid LevelManagers" opined about the need of India to develop its middle level managerial strength. He highlighted that "Chinese firms are efficient because they are autocratic. Autocracy is a common trait in many private Indian companies but we don't see the same level of efficiency. The best of talents are not selected by meritocratic processes but through genetic lotteries of some sort".

However, in company $\mathrm{Y}$, the entrepreneurial culture $(\mathrm{M}=3.3860)$ has a high impact wherein initiatives such as training need analysis, competency mapping, empowerment, participatory style of decision making, etc., have a high influence on the performance of the employees. The regression analysis results show that $76.3 \%$ of the variation in the impact of culture on the performance is caused by the technocratic and entrepreneurial cultures selected in the regression model.

\section{Recommendations}

The following recommendations are being made on the basis of the results for the selected companies $\mathrm{X}$ and $\mathrm{Y}$, which belong to the private sector.

According to the analysis, private sector company $\mathrm{X}$ is dominated by an autocratic culture and company $\mathrm{Y}$ by an entrepreneurial culture. There is a positive correlation between a strong technocratic culture and the level of motivation $(\mathrm{r}=0.560)$. Hence, the organization should focus on strengthening the technocratic culture in the organization, if they want to have higher levels of motivation and lower levels of dissatisfaction. Furthermore, there is a negative correlation $(r=-0.427)$ between the autocratic culture and motivation, hence the organization should reduce its autocratic culture and strengthen the technocratic culture.

Work culture promotes or restricts certain needs. The need for control $(\mathrm{M}=2.7024)$ amongst the middle management employees of organization X needs to be promoted. This shows that there is some dissatisfaction with the level of control that the middle level managers can actually exercise. The interpersonal need for control is defined as the need to establish and maintain a satisfactory relationship with people with respect to control and power. It refers to the extent the employees feel themselves as competent and responsible. If the middle level managers felt competent and responsible, they would be able to mutually respect others on the same parameters. Organization Y requires more opportunities to its middle level managers to fulfill their need for achievement $(M=2.6704)$ than they actually get. Results show that a rigid authoritarian corporate culture might initially translate into positive work output in the short-term but leads to long-term workplace dissatisfaction. This is supported by the study of Reinemer (1995), where he emphasizes 
that employees' involvement in structuring work is also a prime requirement for role satisfaction.

The results of the regression show that various types of culture impact on the motivation level and therefore, the organization needs to nurture and develop the right type of culture in the organization to foster the motivation level of the employees working in the organization. The goal is not just to survive, but also to prevail, prosper, and achieve something much broader and bigger than mere survival.

The analysis shows that the private sector is dominated by the autocratic culture while the regression analysis results show that $76.3 \%$ of the variation in the impact of culture on the performance is caused by the technocratic and entrepreneurial cultures. So, organizations should endeavor to promote the technocratic or entrepreneurial culture as the dominant one, while the correlation also shows that the technocratic culture has a high correlation with career planning, participative decision making, redressal handling, innovation, autonomy, etc., as compared to the entrepreneurial culture. Hence, organizations must endeavor to strengthen their technocratic culture in order to enhance the performance of their employees at the middle management level. Organizations that are able to optimally utilize and maximize human performance have a competitive edge over others.

\section{References}

ASHKANASY, N.; WILDERON, C.; PETERSON, M. F. 2000. Handbook of Organizational Culture and Climate. Thousand Oaks, CA : Sage, 2000, s.1-18.

BLACKLER, F. H. M.; BROWN, C. A. 1981. A New Philosophy of Management: Shell Revisited. Personnel Review. 1981, vol. 10, s. 15-21.

BORMAN, W. C.; MOTOWIDLO, S. J. 1993. Expanding the Criterion Domain to Include Elements of Contextual Performance. In SCHMITT, N.; BORMAN, W.C. and Associates (eds.). Personnel Selection in Organizations. San Francisco : Jossey-Bass, 1993, s.71-89.

BODLEY. 1994. Cultural Anthropology: Tribes, States and the Global System. Mayfield, CA : Mountain View, 1994.

BORDENS, K. S.; ABBOTT, B. B. 1996. Research Designs and Method. Mayfield, USA, 1996.

DENNISON, D. 1984. Bringing Corporate Culture to the Bottom Line. Organizational Dynamics. 1984, vol. 13, s. 4-22.

DEAL, T.; KENNEDY, A. 1982. Corporate Culture: The Rites and Rituals of Corporate Life. Massachusetts : Addison-Wesley Publishing Company, 1982.

EGAN, T. M.; YANG, B.; BARTLETT, K. R. 2004. The Effects of Organizational Learning Culture and Job Satisfaction on Motivation to Transfer Learning and Turnover Intention. Human Resource Development Quarterly. 2004, vol. 15, s. 279-301.

GORDON, G. G.; DITOMASSO, N.; 1992. Predicting Corporate Performance from Organizational Culture. Journal of Management Studies. 1992, vol. 29, s. 783-98.

KHANNA, T. 2010. Focus On Mid Level-Managers. Business World. 2010. www.businessworld.in/ bw/2010_08_13_Focus_On_Midlevel_Managers.html.

PAREEK, U. 1997. Training Instruments for Human Resource Development. 2nd ed. New Delhi : Tata McGraw Hill, 1997, s. 671-683.

PATTANAYAK, B. 1998. Corporate HRD. New Delhi : Excel Books, 1998, s. 26-40.

PASCALE, R. T.; ATHOS, A. G. 1981. The Art of Japanese Management: Application for American Executives. New York : Simon \& Schuster, 1981 
PETERS, T.; WATERMAN, R. 1982. In Search of Excellence. New York : Random House, 1982.

REINEMER, M. 1995. Work Happy. American Demographics. 1995, vol. 17, s. $26-30$.

SLEDGE, S.; MILES, A.; COPPAGE, S. 2008. What Role Does Culture Play? A look at Motivation and Job Satisfaction among Hotel Workers in Brazil. International Journal of Human Resource Management. 2008, vol. 19, s. 1667-1682.

TAKADA, P. W.; WESTBROOK, J. W. 2009. The Impact of Organization Culture on Satisfaction of Engineers in Technology. University of Alabama in Huntsville. 2009. [cit. 2009-02-27]. http://ntrs. nasa.gov/archive/nasa/casi.ntrs.nasa.gov/20020017756_2002010173.pdf.

TABACHNICK, B. G.; FIDELL, L. S. 1983. Using Multivariate Statistics. New York : Harper \& Row, 1983.

\title{
IMPACT OF WORK CULTURE ON MOTIVATION AND PERFORMANCE LEVEL OF EMPLOYEES IN PRIVATE SECTOR COMPANIES
}

\begin{abstract}
Work culture has the potential to enhance managerial performance. The objective of the present study is to examine the dominant work culture prevalent in the two private sector manufacturing organizations $X$ and $Y$ and to study its impact on the contextual performance and motivation level of the employees at the middle management level. The statistical tools used to test the hypothesis were the mean, standard deviation, t-test, correlation, one-way ANOVA, and regression. The findings show that the technocratic culture has the strongest partial correlation or the purest relationship with role motivation. Through a regression analysis, the technocratic culture emerges as a strong predictor of motivation while the entrepreneurial culture as a strong predictor for performance. The findings imply that when individuals are satisfied with their roles and feel that their supervisor or leader provides them with support, their contextual performance is expected to increase.
\end{abstract}

Keywords: Work culture, autocratic culture, bureaucratic culture, technocratic culture, entrepreneurial culture, dominant culture, contextual performance, role motivation

JEL Classification: D2, J24, O15 